TEME, г. XLIV, бр. 3, јул - септембар 2020, стр. 1039-1053

Прегледни рад https://doi.org/10.22190/TEME180824066L

Примљено: 24. 8. 2018.

UDK 316.744:349.2

Ревидирана верзија: 7. 5. 2019.

Одобрено за штампу: 1. 10. 2020.

\title{
УЛОГА КОМУНИКАЦИЈЕ У ПОВЕЪАЊУ \\ ЕФИКАСНОСТИ У РАДУ РЕПУБЛИЧКЕ АГЕНЦИЈЕ ЗА МИРНО РЕШАВАЊЕ РАДНИХ СПОРОВА
}

\author{
Ивица Лазовић ${ }^{*}$, Предраг Јеленковић² \\ ${ }^{1}$ Републичка агенција за мирно решавање радних спорова, Београд, Србија \\ ${ }^{2}$ Факултет за културу и медије, Београд, Србија \\ *ivica.lazovic@ramrrs.gov.rs
}

\begin{abstract}
Апстракт
У раду се бавимо улогом и значајем комуникације у повећању ефикасности Републичке агенције за мирно решавање радних спорова. Иако је комуникација свеприсутна, често јој се не приступа систематски и бивају занемарени њена улога и место у функционисању организације. На основу анализе и истраживања, у раду се приказује како је кроз системски приступ комуникацији у функционисању једног државног органа дошло до веће ефикасности. Анализира се комуникација у оквиру поступака и метода мирног решавања радних спорова, у мирењу и арбитражи, али и са корисницима услуга Агенције, пре свега грађанима. Указује се и на основне показатеље доприноса унапређене комуникације, односно на број поступака и статистичке параметре који то доказују.
\end{abstract}

Кључне речи: мирење, посредовање, арбитража, радни спор, комуникација.

\section{THE ROLE OF COMMUNICATION \\ IN THE INCREASE OF THE EFFICIENCY IN THE WORK OF THE REPUBLIC AGENCY FOR PEACEFUL SETTLEMENT OF LABOR DISPUTES}

\section{Abstract}

In this paper we deal with the role and importance of communication in increasing the efficiency of the Republic Agency for the Peaceful Settlement of Labor Disputes. Although communication is ubiquitous, it is often not accessed systematically and its role and place in the functioning of the organization is ignored. Based on the analysis and research in the paper, it is shown that through a systemic approach to communication in the work of one state body, there has been greater efficiency. Communication is analyzed in procedures and methods of peaceful settlement of labor disputes, arbitration and mediation, as well as with users of services of Agency, primarily the civil society. It also points to the basic indicators of the contribution of the improved communicator to the number of procedures and statistical parameters.

Key words: conciliation, mediation, arbitration, labor dispute, communication. 
Републичка агенција за мирно решавање радних спорова основана је по узору на јавне службе за мирење и посредовање у англосаксонском праву, посебно на британску Службу за саветовање, мирење и арбитражу и америчку Федералну службу за мирење и посредовање. Циљ увођења овог институционализованог начина решавања радних спорова у наш правни систем био је да се афирмишу методи мирног решавања радних спорова и смањи учесталост штрајкова (Лубарда, 2012, стр. 944).

Ова агенција за мирно решавање радних спорова је правни основ за постојање добила Законом о мирном решавању радних спорова из 2004. године како би обављала стручне послове који се односе на мирно решавање колективних и индивидуалних радних спорова, затим на избор миритеља и арбитара, вођење именика миритеља и арбитара, стручно усавршавање миритеља и арбитара, одлучивање о изузећу миритеља и арбитара, вођење евиденције о поступцима мирног решавања радних спорова и друге послове одређене законом (Закон о мирном решавању радних спорова, 2004, чл. 8). Агенција је основана као посебна организација у систему државне управе Републике Србије. Такође, Агенција је почела са радом 2005. године и иза себе има сада већ скоро 15 година искуства и праксе.

Агенција је образована да делује и ради као орган државне управе и, као таква, примењује све прописе који се односе и на остале државне органе извршне гране власти, а пре свега законе којима се уређује службенички систем и поступање, Закон о општем управном поступку, Закон о државној управи, Закон о државним службеницима.

\section{ВРСТЕ РАДНИХ СПОРОВА У НАДЛЕЖНОСТИ}

Разликујемо две врсте радних спорова у надлежности ове агенције, а то су колективни и индивидуални спорови.

Под колективним радним спором се, у смислу Закона о мирном решавању радних спорова, сматрају спорови поводом закључивања, измена и/или допуна колективног уговора; примене колективног уговора у целини или његових појединих одредаба; примене општег акта којим се регулишу права, обавезе и одговорности запослених, послодавца и синдиката; остваривања права на синдикално организовање и деловање и остваривање права на утврђивање репрезентативности синдиката код послодавца; штрајка; остваривања права на информисање, консултовање и учешће запослених у управљању и утврђивања минимума процеса рада у складу са законом. По овом закону, стране у колективном спору су учесници колективног уговора у складу са законом, односно послодавац, синдикат, запослени или представник 
запослених - у односу на примену колективног уговора или општег акта и остваривање колективног права, у складу са законом (Закон о мирном решавању радних спорова, 2004, чл. 2).

Индивидуалним радним споровима, у смислу закона, сматрају се спорови поводом отказа уговора о раду; радног времена; остваривања права на годишњи одмор; исплате зараде/плате, накнаде зараде/плате и минималне зараде у складу са законом; исплате накнаде трошкова за исхрану у току рада, за долазак и одлазак са рада, регреса за коришћење годишњег одмора и друге накнаде трошкова у складу са законом; исплате отпремнине при одласку у пензију, јубиларне награде и других примања у складу са законом и дискриминације и злостављања на раду. Страном у индивидуалном спору сматра се запослени и послодавац (Закон о мирном решавағу радних спорова 2004, чл. 3).

Закон предвиђа пружање услуга грађанима које се темеље на обраћању Агенцији, а која је детаљно разрађена према Правилнику о поступку мирног решавања радног спора. Предлог за покретање поступка мирног решавања радног спора подноси се у писменом облику и предаје непосредно Републичкој агенцији за мирно решавање радних спорова или се шаље поштом, а може се поднети и путем телефакса или електронске поште (Правилник о поступку мирног решаваға радног спора, 2005, чл. 1). На наведени начин може се рећи да је први пут у канцеларијско пословање државне управе Републике Србије уведено и прописано комуницирање електронским путем посредством електронске поште. Тадашња, а и још увек важећа, Уредба о канцеларијском пословању (Уредба о канщеларијском пословану органа државне управе, 1992) није прописала такав облик комуникације, док је Уредба о електронском канцеларијском пословању органа државне управе донета тек након пет година од доношења Правилника (Уредба о електронском канцеларијском пословању, 2010).

\section{ПОЛАЗИШТА ЗА РАЗВОЈ КОМУНИКАЦИЈЕ}

Иако су полазишта за развој комуникације дата у прописима, у пракси је због бројних сложених околности и разлога развој комуникације ишао споро. Разлоге првенствено треба тражити и у томе што у нашој широј друштвеној јавности, а посебно на пољу права, треба доста времена да се развије теоријска основа и прихвати значај примене научних знања о комуникацији. Са̂м теоријски приступ комуникацији је мултидисциплинаран, а посебно је сложена практична примена модерних комуникацијских техника. Међутим, примена комуникације у контакту са грађанима, као корисницима услуга, јако је широка. Она се прожима и односи и на поступке као што су управни, парнични, на медијације, арбитраже, мирења итд. 
Са друге стране, комуникологија има богату теоријску основу и практичну примену. Сама реч комуникаиија вишезначна је и има различите употребе у свакодневном говору.

„Тако се значења ових термина, дакле и глагола комуницирати и именице комуникација, протежу од саопштавања, јављања, обавештења, преношења знања, споразумевања, размене мисли, идеја, осећања, саучествовања у нечему, преко преношења порука, информација, па све до разговора, разумевања, духовног дружења, општења, па чак и слагања (са другим).” (Томић, 2003, стр. 30)

Комуникација представља процес размене који, по правилу, укључује размену више од једне поруке истовремено. Смисао комуникације је, дакле, садржан у размени порука, чије су функције упозорење, савет, информација, убеђивање, изражавање мишљења или чак уживање. Поруке које се размењују у процесу комуницирања ретко су неутралне. Неке поруке су јасне и очигледне, док су друге скривене и нејасне. Другим речима, у неком комуникативном процесу могу се намерно скривати одређене поруке, као што се могу појавити и неке поруке које комуникатор није хтео да саопшти. У друштвеним наукама, под појмом комуникација се подразумева укупност различитих облика веза и додира између припадника друштва (Јеленковић, 2013, стр. 236).

Друштвена реалност је свакако незамислива без комуникационих односа и веза, јер је комуницирање веома сложен и вишедимензионалан феномен који се временом шири, појављује и нестаје испод површине многих друштвених појава које изучавају друге етаблиране научне дисциплине (Ранђеловић, Јеленковић, 2012, стр. 235, 265).

Од ове реалности није изузета ни државна управа, комуникација је њена нужност и део свакодневног рада, спада у права која се подразумевају. Међутим, „право на комуницирање”, као такво, не постоји у одредбама међународног права. Ипак, право на комуницирање изазвало је жучне дебате још од времена када је Жан Д’Арси (Jean d'Arsi) први пут 1969. године изговорио те речи. У годинама дебата које су уследиле, УНЕСКО Организација за образовање, науку и културу Уједињених нација (UNESCO - United Nations Educational, Scientific and Cultural Organization) постала је параван за сукобљавање хладноратовских приступа, посебно након што су САД и Велика Британија напустиле Организацију после прихватања извештаја Мек Брајдове (Sean MacBride) комисије 1980. године. Комисија (International Commission for the Study of Communication Problems) објавила је коначан извештај под називом „Много гласова - један свет: Комуникације и друштво данас и сутра”, у коме је закључила да „препознавање права на комуницирање, као индивидуалног и друштвеног права обећава напредак ка демократизацији комуницирања". У овом извештају су 
детаљно дате многобројне препоруке, укључујући и ону бр. 54, која позива на проширење права:

\begin{abstract}
„Потребе за комуницирањем у демократском друштву морају се остварити проширењем посебних права попут права на информисање, права да се буде информисан, права на приватност, права на учешће у јавном комуницирању - што су све елементи новог концепта, права на комуницирање". Дакле, упркос томе што је почетак дебате био у сенци пажње која се поклањала државним актерима, не сме се заборавити да корени права на комуницирање леже у људском достојанству (Хамелинк, Холфман, 2009, стр. 10).
\end{abstract}

Говор и разговор, као реторичке теме, били су у средишту пажње још од времена античких филозофа класичног периода, а недоумица да ли је добар говорник онај који говори истину или добро говори представља и данас не само реторички него и прворазредни комуниколошки проблем, вододелницу у херменеутици ове науке. Уосталом, уз ризик извесног поједностављења у уопштавању, може се приметити да је логичко-етички правац (Платон: „Реч у душе грађана усађује праведност”) у античкој реторици извршио и врши утицај на европске комуникологе, сличан оном који је формално-естетички правац (Горгија: „Оно што је изречено није идентично ономе што је речено") имао на главну струју у америчкој теорији комуницирања (Богданић, 1996, стр. 41). Реторичким проблемима у старом Риму посебно су се бавили Цицерон и Квинтилијан. Квинтилијан је својим делом Образовање говорника у Риму засновао реторику и као теоријску дисциплину, сматрао је да јасност у излагању прва претпоставка доброг стила (,Људи се познају по изговору као ковина по звекету”), али је моћ добре беседе у изазваним осећањима (,У емоцијама се огледа сва снага говорништва") (Милетић, 2005, стр. 4).

Треба истаћи да и начин на који нека особа доживљава себе у великој мери условљава и начин њене перцепције друге особе, а тиме и модел комуникације са том особом. Наиме, перцепција других један је од најважнијих елемената социјалне интеракције. Процес оцењивања и диспозиција појединаца на основу њихових акција названи су у социјалној психологији атрибуционим процесом. Фриц Хајдер (Fritz Heider) у својој студији испитивао је начин на који људи оцењују узроке и последице догађаја који се око њих дешавају (Heider, 1958). Људи процењују једни друге посматрајући их, како при првом сусрету тако и касније. Процењивање других људи најчешће се темељи на посматрању невербалних знакова и представља низ нагађања заснованих на предрасудама, знању и искуству. 
„У процесу перцепције других, међутим јављају се извесни проблеми који се тичу пројектовања наших жеља у слику о другој особи, закључивања на основу погрешних претпоставки, категоризације људи на основу предрасуда, склоности да први утисак детерминише мишљење о некој особи. Са друге стране и етнички стереотипови могу значајно утицати на процес перцепције других, посебно оних који не припадају нашој етничкој или културној заједници.” (Томић, 2003, стр. 66)

Комуникација је основна људска потреба и активност, континуална у простору и непрестана у времену, усмерена према спољашњем свету и према унутрашњем бићу. Она је процес помоћу кога разумемо друге и заузврат настојимо да нас други разумеју, а укључујући све процесе путем којих један ум утиче на други, односно, у коме један систем утиче на други (Бањанин, 2003, стр. 8), као и уверење да комуникација, између осталог, представља процес планираног и контролисаног циљног општења (Томић, 2003, стр. 77).

У савременом информатичком друштву и свету рада, где је информација кључни ресурс, а комуникација битан пословни процес, потребно је разликовати једносмерни и двосмерни комуникациони процес. Једносмерни комуникациони процеси су карактеристични за бирократске организације и прати их хијерархијска, уска и силазна комуникација, док се двосмерна или демократска комуникација одликује ширином, разумевањем, повратном информацијом и сложеношћу, али и спорошћу, јер захтева време за разумевање (Миљевић, 2011, стр. 254).

Битно је напоменути да се комуникација у организацијама одвија кроз комуникационе канале, који су средства за практично преношење информација. Они се могу поделити на формалне и неформалне канале, а често у теорији нису ни сви обрађени, те могу бити сачињени од писама, мејлова, разних медија, па све до до интернета, телефона, скупова, разних промоција (Миљевић, 2011, стр. 258).

\section{ПРЕПОЗНАВАЊЕ ПРОБЛЕМА И ПРАКТИЧНА ПРИМЕНА КОМУНИКАЦИЈЕ}

Државна управа, по правилу, поред извршавања строго дефинисаних надлежности, ретко прави искораке у смислу асистенције науке и научних сазнања на унапређењу функционисања и свакодневног рада. Наведено важи и код приступа комуникацији, планирању и обраћању јавности на методичан начин. Иако су модерне доктрине новог јавног менаџмента и управљања квалитетом донеле промене у раду државних органа, што се огледа од приступа информацијама од јавног значаја, па до развоја електронске управе, ипак се 
практична примена свих иновација спроводи споро (Стратегија реформе јавне управе у Републиии Србији, 2014).

Данас је сасвим јасно да је значај примене сазнања у области комуникације у друштвеним наукама, пре свега, у праву, али и политици и економији, од суштинског значаја за ефикасност, квалитет обављања делатности и задовољство корисника услуга јавног сектора. Од Служби за односе са јавношћу (Public relation), разних кампања, промоција, дана управе, писане и усмене комуникације, телефонске комуникације, електронске комуникације и коришћења интернет портала и сервиса за грађане, комуникација је заправо свеприсутна у управи и изражава њену суштину и форму. Подручје свакодневне примене комуникације у управи јако је широко, без обзира на то што у пракси често није предмет посебног интересовања и аналитичног приступа.

У складу са доминантним трендом, и Републичка агенција за мирно решавање радних спорова, као један од органа државне управе, такође је примењивала различите облике комуникације, којима није приступала аналитично и систематски. Посебно није придавана пажња двосмерној комуникацији и није се користила могућност циљане примене комуникационих канала (Иницијатива за развој $и$ сарадюу, 2013).

Међутим, од 2014. године приступ комуникацији је промењен, jep је она била предмет дубинске анализе. Резултат те анализе и асистенције науке јесте да је препознат проблем у претходном поступању и потпуно је промењен стари приступ комуникацији, а све у циљу унапређења и побољшања стања (Инииијатива за развој и саpadюry, 2013).

Почетно стање било је такво да се на годишњем нивоу решавало око 200 предмета пред том агенцијом и било је присутно уверење да правни институт мирног решавања радних спорова није довољно видљив и афирмисан у нашем правном систему. Такође, имајући у виду то да се поступци решавају на основу добровољног приступа, у том периоду је сагласност за мирно решење спора добијана код сваког четвртог предлога (Лазовић, Радивојевић, 2015, стр. 77).

У циљу откривања узрока таквог стања, спроведено је истраживање о мирном решавању радних спорова. Ово истраживање спровео је невладин сектор, организација Иницијатива за развој и сарадњу, која се бави унапређењем радних и социјалних права. Ова организација спровела је истраживање у сарадњи и са социјалним партнерима, репрезентативним синдикатима и удружењем послодаваца у три града: Београду, Новом Саду и Нишу. Резултати истраживања објављени су у приручнику Истраживање о мирном ремавању радних спорова у Београду, Новом Саду и Нишу, с посебним освртом на пољопривреду, прехрамбену, дуванску индустрију и водопривре- 
ду, грађевинску и индустрију грађевинског материјала, хемију и неметале (Иницијатива за развој и сарадњу, 2013).

Након спроведеног истраживања, дошло се до сазнања која су указала на то да су различити фактори и околности утицали да институт мирног решавања радних спорова остане недовољно видљив и афирмисан у нашој средини и након више од деценију његове примене. Истраживање је указало на то да су многа ограничења настала услед неинформисаности, незаинтересованости и недостатака у законодавном оквиру, па је таква ситуација довела до тога да судска заштита остане примарни облик заштите права запослених. И поред свих предности које институт мирног решавања радних спорова носи, он није успео да се након првих десет година постојања на одговарајућ начин постави као алтернатива судовима, који и даље остају примарни облик заштите. Истраживање је указало на два кључна недостатка, на формално-правне недостатке и лошу комуникацију (Иницијатива за развој и сарадњу, 2013, стр. 82). Формално-правни недостаци су се односили првенствено на непрецизне рокове и уску надлежност. Са друге стране, све је указивало на то да је доминантан метод комуникације бирократски и једносмеран, уз веома скромно коришћење могућих комуникационих канала.

У циљу унапређења ситуације, на темељима сазнања добијених наведеним истраживањем, анкетама, кроз дубински интервју и на округлим столовима у Београду, Новом Саду и Нишу, а на узорку који су чинили заинтересована јавност, запослени, синдикати и послодавци, од 2014. године у овој агенцији предузимају више мера. Ове мере увођене су систематски и постепено кроз више корака. Циљеви су били да се, у складу са анализом, унапреди комуникација и да се све нормативне неусаглашености коригују кроз унапређење прописа. Циљ је био да се једносмерна бирократска комуникација усмери ка двосмерној демократској комуникацији уз укључивање што више комуникационих канала - како у поступцима тако и у односу ка корисницима услуга овог државног органа. За могуће комуникационе канале изабране су модерне технологије, интернет, телефон, медији, али и штампа, билтени, плакати, приручници и директан разговор.

\section{Методе решавања радних спорова и улога комуникаџије у поступцима}

Прво запажање након наведеног истраживања Истраживањ $а$ о мирном решавању радних спорова у Београду, Новом Саду и Нишу било је да до спорова често долази због неразумевања и лоше комуникације и да је комуникација често узрок проблема.

У савременим друштвима и различитим системима радно-правних односа неминовност је да се јављају конфликти који доводе до 
радних спорова, а начини решавања тих спорова се у конкретним политичко-правним системима међусобно разликују. Те методе могу бити и формалне и неформалне, а могу се разликовати и од врсте спора - да ли се ради о индивидуалним или колективним радним споровима. Истраживање је указало на два правца комуникације на која треба обратити пажњу, а то је комуникација ка споља и комуникација унутар поступка. Прва се односи на јавност и грађане, а друга на комуникацију у оквиру поступака за мирно решавање радних спорова. У наредном делу ћемо се осврнути на комуникацију у оквиру поступака за мирно решавање радних спорова.

Најчешћи коришћени метод у колективним споровима јесте мирење, а то је доминантан метод и у нашем правном систему за решавање колективних радних спорова. Мирење се одређује као пружање помоћи странама у спору од стране помиритеља, који настоји да их увери у потребу да се састану и расправљају о предмету спора како би се лакше споразумеле о решењу спора и саме дошле до прихватљивог решења (Кулић, 2007, стр. 36). То значи и да је задатак миритеља да убеди стране у спору да дођу до прихватљивог и праведног решења. Дакле, снажно средство, поред познавања материје и припреме, јесте и комуникациона способност миритеља у циљу убеђивања страна у спору. Ако мирење успе, саставља се писани споразум, опет резултат комуникације и разумевања, а у супротном се констатује неуспех мирења.

Најчешће се говори о факултативном мирењу, које је добровољно и уређено у општем правном режиму кроз прописе о посредовању, затим обавезном мирењу пре евентуалног обраћања арбитражи и пре прибегавања методима директне индустријске акције као што су штрајк и обустава рада (Кулић, 2007, стр. 364).

Други метод за решавање радних спорова пред овом агенцијом јесте арбитража. Она подразумева поверавање трећем лицу, или лицима, решавање спора. Арбитар, односно арбитража, доноси правно обавезујућу одлуку, којом се спор правноснажно окончава, осим у случају тзв. саветодавне арбитраже (Кулић, 2007, стр. 365).

Арбитража се сматра за најзначајнији, најподеснији и најраспрострањенији метод за решавање радних спорова, који карактерише поверавање решавања спора арбитру или арбитражном већу (Кулић, 2007, стр. 366).

Арбитражу спроводе арбитри, који могу бити неутрални, што је најчешће правило, али могу бити и из редова самих страна у спору. Арбитража се најчешће дели на правну и интересну. Правна арбитажа је она где се ради о решавању спорова који настају поводом тумачења и примене одредаба важећих колективних уговора о колективним правима запослених, односно послодавца, у важећим законским и подзаконским актима. Задатак арбитра, односно арбитраже, 
јесте да протумачи колективни уговор, односно да примени право на дати случај. Само тумачење одредаба, али и преношење садржаја истих, заправо се своди на питање које је потребно и могуће посматрати као комуниколошки проблем (Кулић, 2007, стр. 367).

Интересна арбитража подразумева решавање колективних радних спорова који настају у поступку закључивања и/или измена и допуна колективног уговора, поводом питања која треба да буду регулисана у новом колективном уговору. Она подразумева познавање колективног уговора, али и комуникацијске вештине преговарача (Кулић, 2007, стр. 367).

Одлуке арбитраже могу бити правно обавезујуће или необавезујуће, зависно од тога како је то у конкретном систему уређено законским или подзаконским актима. У нашем случају, арбитражне одлуке су, по правилу, коначне и само изузетно се могу оспоравати. Разлози за побијање арбитражних одлука су у свим системима строго ограничени и своде се на повреду уставног и јавног поретка (Кулић, 2007, стр. 368).

На основу Закона о мирном решавању радних спорова, арбитража је одређена као метод за решавање индивидуалних радних спорова и кључну улогу имају независни арбитри који мериторно одлучују о предмету спора. Они су ти од чијег знања и компетентности, али и вештина комуникације, зависи решење спора.

Комуникација у оба метода, мирењу и арбитражи, има важно место, али јој се никада није системски приступало, већ се она подразумевала као битна претпоставка и нужност поступка. Међутим, често је била узрок проблема, стварања неповерења међу странама у спору уколико се посвети већа пажња некој од страна у спору и слично (Иницијатива за развој и сарадњу, 2013).

Мера која је предузета од стране наведене агенције да би се унапредило стање у области комуникације била је обука миритеља и арбитара о значају и улози комуникације и јачање комуникацијских вештина, те је организовано више обука у циљу подизања вештина миритеља и арбитара и јачања знања и вештина и о комуникацији.

Улога комуникачије у циљу афирмачије мирног решавања радних спорова код грађана и веће ефикасности Агеничје

Поред препознавања улоге комуникације у поступцима, на основу анализа, а у циљу унапређења стања у области мирног решавања радних спорова, у Агенцији су предузели активности и на јачању комуникације према јавности, а пре свега према грађанима. Ове мере су увођене систематски и постепено кроз више корака. Истраживање о мирном решавағу радних спорова у Београду, Новом Саду и Нишу, на основу кога се износе даље чињенице, указало 
је на то да шира јавност није упозната са постојањем овог института, а ако и јесте, онда је то врло површно и непрецизно (Иницијатива за развој и сарадњу, 2013, стр. 78).

Како би се дао одговрајућ одговор на непрестану потребу за активнијом комуникацијом са заинтересованом јавношћу и унапређењу постојећег стања, предузето је више мера са идејом постизања двосмерности у комуникацији и укључивања грађана. Такође, намера је била и да се на унапређењу користи што већи број комуникационих канала, почев од интернета, па све до непосредног разговора. Као показатељи резултата праћени су број покренутих поступака као директан показатељ и проценат добијених сагласности да се поступак решава мирним путем.

Први комуникациони канал који је коришћен за побољшање комуникације био је интернет. У Агенцији су почели од унапређења интернет презентације, развијена је двосмерност комуникације кроз могућност праћења тока покренутих поступака од стране учесника у поступку, а посетиоцима интернет презентације омогућено је да у неколико корака сазнају све о институту мирног решавања радних спорова, чиме је постигнута транспарентност у раду Агенције. Представљене су неке предности поступака пред Агенцијом у односу на суд, као и решења у пракси. У ову агенцију су увели и интеракцију са заинтересованим корисницима, а посебно са странама у поступку.

Такође, уведено је пружање правне помоћи, путем интернета, отворена је могућност постављања питања, а процес комуникације је поједностављен и убрзан, док су трошкови класичне поштанске преписке на тај начин превазиђени. Посвећена је одређена пажња и порталу електронске управе како би сви корисници могли приступити најважнијим садржајима преко овог портала, као што су електронске услуге, вести, питања итд.

Интернет је коришћен и као средство за комуникацију са послодавцима, па је послужио за курс за послодавце о поступку мирног решавања радних спорова, који је постављен на сајт ове агенције. Циљ овог курса био је да се кроз кратку видео-презентацију послодавци упознају са предностима мирног решавања радних спорова, као и о предностима решавања спорова мирним путем. У циљу двосмерности комуникације, након одгледане презентације, био је осмишљен и тест у циљу провере колико је схваћена презентација и институт мирног решавања радних спорова.

На пољу комуникационих технологија у последњих неколико година мобилни телефони преузимају примат над стандардним персоналним рачунарима, те је у оквиру свих предузетих мера у овој агенцији осмишљена апликација за мобилне телефоне о мирном решавању радних спорова. Ова апликација је подржавала комуникацију и размену информација за све заинтересоване за мирно решавање 
радних спорова, кроз могућност постављања питања и покретања поступка путем мобилног телефона. Она је служила и за миритеље и арбитре кроз стручни форум у циљу уједначења праксе и јачања међусобне комуникације.

Унапређена је и класична телефонска комуникација кроз „СОС мобинг телефон” како би позивањем бесплатног телефонског броја грађани добили одређене информације о злостављању на раду и правну подршку.

Имајући у виду да су за мирно решавање радних спорова свакако заинтересовани и многи који нису корисници интернета, у циљу приближавања комуникације са овом најважнијом групом, осмишљени су промотивни плакати и леци. Они су промовисани преко синдиката, послодаваца или других државних органа. Наведене организације су даље преко плаката на видним местима комуницирали са заинтересованима о видовима алтернативног решавања радних спорова.

Унапређењу комуникације са грађанима допринели су и директни разговори. Кроз сарадњу са синдикатима, одржане су радионице на којима је циљ био да се поступак приближи запосленима и послодавцима, кроз презентацију института мирног решавања радних спорова и симулацију поступка мирног решавања радног спора. На наведени начин, остварена је двосмерност у комуникацији, отклоњене су дилеме кроз питања и конкретна искуства.

За стручну и компетентну јавност из ове агенције издат је Приручник о добрим праксама у мирном решавању радних спорова, у коме су представљени пракса и искуство у мирном решавању индивидуалних и колективних радних спорова кроз искуства социјалних партнера, Агенције и посебно кроз практична искуства миритеља и арбитара (Иницијатива за развој и сарадюу, 2013, стр. 78).

Важан комуникациони канал јесу и медији, па је посвећена и одређена пажња комуникацији путем медија и информисању шире јавности о постојању и улози института мирног решавања радних спорова, о надлежностима и резултатима рада ове агенције, као и услугама које нуди. Агенција је практиковала и редовно праћење штампаних медија кроз тзв. прес-клипинг (Press clipping) и хитно укључивање у радне спорове, што је допринело повећању видљивости овог правног института (Лазовић, Радивојевић, 2015, стр. 76).

\section{ЗАКЉУЧАК}

У Републичкој агенцији за мирно решавање радних спорова, уз асистенцију науке и савремених сазнања у области комуникације, у претходне четири године интензивно се радило на спровођењу више екстерних и интерних мера у циљу унапређења комуникације. Спроведен је низ мера како би се комуникација од бирократске је- 
дносмерне трансформисала у двосмерну и коришћен је широк круг комуникационих канала. Након свих спроведених мера на пољу унапређења комуникације, приметни су одређени помаци у погледу два кључна показатеља праћења, а то су укупан број поступака пред Агенцијом и проценат добијених сагласности.

Све наведене мере имају за резултат извесну прогресију броја поступака у односу на период до 2014. године, за чак пет пута. Од 2010. до 2014. године пред Агенцијом се годишње просечно решавало 200 радних спорова. У 2015. години је број поступака решаваних пред Агенцијом порастао на 322, да би у 2016. години тај број износио 956 поступака, а у 2017. години је решавано 1074 поступка. Такође, сагласност да се поступци решавају мирним путем добијена је код 70\% поднетих предлога (Лазовић, Радивојевић, 2018, стр. 126).

На основу свега наведеног, може се рећи да је унапређење комуникације у савременом добу нужна претпоставка ефикасног функционисања свих организација, па и органа државне управе и, могли бисмо рећи, основ за сваки развој и свако функционисање.

У циљу ефикасног вршења надлежности из свог делокруга и упознавања јавности са делокругом свог рада, органи државне управе морају да комуникацији приступе плански, систематично и на темељима научних сазнања. Наведено потврђује пример предузетих мера за унапређење комуникације у Агенцији, која је била предмет нашег интересовања.

\section{ЛИТЕРАТУРА}

Heider, F. (1958). The Psyhology of Interpersonal relations, New York: Willey.

Бањанин, М. (2003). Динамика комуникације [The Dynamics of Communication], Мегатренд универзитет, Београд.

Богданић, А. (1996). Комуникологија [Communication], Чигоја штампа, Београд.

Закон о мирном решавању радних спорова [Law on Peaceful Settlement of Labor Disputes], Службени гласник PC, бр. 125, 104, 50, (2018)

Иницијатива за развој и сарадњу, Истраживање о мирном решавању радних спорова у Београду, Новом Саду и Нишу [Research on Peaceful Settlement of Labor Disputes in Belgrade, Novi Sad and Nis] (2013).

Јеленковић, П. Јеленковић, Љ. (2013). Системи комуникације у функцији избора професије студија случаја Ниш [Communication Systems in the Function of Choosing the Profession - Case Studies Nis], Теме, Бр. 2, Ниш.

Кулић, Ж. (2007). Индустријски односи [Industrial Relations], Мегатренд универзитет, Београд.

Лазовић, И. Радивојевић, М. Стање у области мирног мирног решавања радних спорова у Републици Србији и осврт на рад Републичке агенције за мирно решавање радних спорова [The situation in the field of peaceful peaceful settlement of labor disputes in the Republic of Serbia and a review of the work of the Republic Agency for peaceful settlement of labor disputes], Радно и социјално право - часопис за теорију и праксу радног и социјалног права, Београд, (2016). 
Лазовић, И. Радивојевић, М. Актуелни токови и могући правци даљег развоја института мирног решавања радних спорова [Current trends and possible directions for further development of institute of peaceful resolution of labor disputes], Радно и социјално право - часопис за теорију и праксу радног и социјалног права, Београд, (2018).

Лубарда, Б. (2012). Радно право, расправа о достојанству на раду и социјалном дијалогу [Labor Law, Debate on Dignity at Work and Social Dialogue], Правни факултет, Београд.

Милетић, М. (2005). Основе комуникологије [Fundamentals of Communication], Универзитет у Крагујевцу, Крагујевац.

Миљевић, М. (2011). Пословна етика и комуницирање [Business Ethics and Communication], Универзитет Сингидунум, Београд.

Правилник о поступку мирног решавања радног спора [Rulebook on the Procedure for Peaceful Settlement of Labor Dispute], Службени гласник PC, бр. 12, 84 (2005)

Ранђеловић, Н, Јеленковић. П. Цртице српске историје права у контексту комуниколошких принципа [Excerpts from Serbian History of Low in the Context of Communication Principles], Зборник радова Правног факултета Ниш, LXII, (2012).

Стратегија реформе јавне управе у Републици Србији [Public Administration Reform Strategy in the Republic of Serbia], Службени гласник PC, бр. 9, (2014).

Томић, 3. (2003). Комуникологија [Communication], Чигоја штампа, Београд.

Уредба о електронском канцеларијском пословању [Regulation on Electronic Office Operations], Службени гласник РC, бр. 40 (2010).

Уредба о канцеларијском пословању органа државне управе [Regulation on the office operations of state administration bodies], Службени гласник РС, бр. 80, (1992)

Хамелинк, С. Холфман, Џ. Стање права на комуницирање [Status of the Right to Communicate], CM Часопис за управљање комуницирањем, Protocol Communications Novi Sad, ФПН Београд, (2009).

\title{
THE ROLE OF COMMUNICATION \\ IN THE INCREASE OF THE EFFICIENCY \\ IN THE WORK OF THE REPUBLIC AGENCY \\ FOR PEACEFUL SETTLEMENT OF LABOR DISPUTES
}

\author{
Ivica Lazović1 ${ }^{\text {, Predrag Jelenković }}{ }^{2}$ \\ ${ }^{1}$ Republic Agency for Peaceful Settlement of Labour Disputes, Belgrade, Serbia \\ ${ }^{2}$ Faculty of Culture and Media, Belgrade, Serbia
}

\begin{abstract}
Summary
In this paper we deal with the role and importance of communication in increasing the efficiency of the Republic Agency for the Peaceful Settlement of Labor Disputes.

The Republic Agency for Peaceful Settlement of Labor Disputes was established by the Law on the peaceful settlement of labor disputes in order to perform professional tasks related to the peaceful settlement of collective and individual labor disputes. As one of the
\end{abstract}


state administration bodies, it has used various forms of communication in its work, which has not been approached analytically and systematically.

However, since 2014, the approach to communication has been changed since it has been subject to in-depth analysis. The result of this analysis and assistance of science is that the problem in the previous treatment has been recognized and the old approach to communication has been completely changed with the aim of improving the situation. The survey has indicated two key disadvantages, the first is bad communication and other formal and legal disadvantages in the legal framework. We also distinguished two ways of communication that we should pay attention to, which is communication from outside and within the process. The first refers to the public and the citizens, and the other to communication within the procedures themselves when applying methods for the peaceful settlement of labor disputes.

With a view to the necessary strengthening and improvement of the situation, a number of measures have been taken on the basis of the knowledge gained from the research. These measures have been introduced systematically and gradually through several steps. The effort was to improve communication, as well as to correct all normative nonconformities through the improvement of regulations.

The measure taken to improve the communication within the procedures themselves when applying methods for the peaceful settlement of labor disputes was the training of conciliators and arbiters about the importance and role of communication and the strengthening of communication skills. More training was organized in order to raise the skills of conciliators and arbiters and to strengthen knowledge, skills and communication.

In order to provide an adequate response to the identified need for more active communication with the interested public and to improve the existing situation, a number of measures have been taken with the idea of achieving two-way communication and citizen involvement. Measures for improved website presentation of legal assistance through the site have been undertaken as well as the introduction of a course for employers, applications for mobile phones, posters, leaflets, manuals and free telephone lines in order to approach citizens and service users.

As a result, the progression of the number of procedures in relation to the previous period is noticeable and amounts to five times. In 2015, the number of procedures settled by the agency rose to 322. In 2016 this number was 956 and in 2017 it was 1074 proceedings. Approval for peaceful settlement of labor disputes has been obtained in $70 \%$ of cases.

Improving communication in contemporary circumstance requires the presumption of the efficient functioning of all organizations and also of state authority and could be the basis for any development and functioning. 